Robert A. Buckle ${ }^{1}$

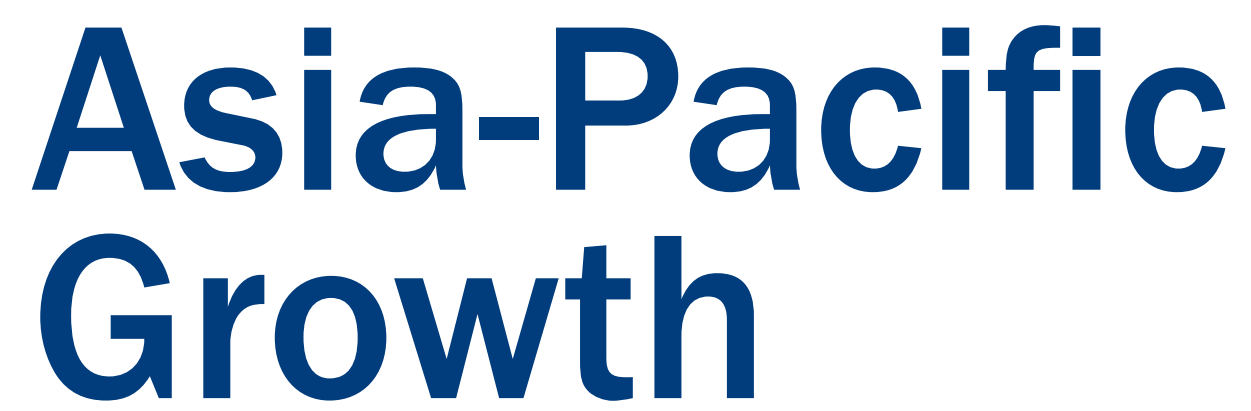

\section{Before and}

\section{After the Global}

Financial Crisis

\section{Introduction}

The modern era of globalisation has

been associated with significant economic

transformation around the world, but also

an increasing frequency of financial crises.

According to Eichengreen and Bordo (2002)

there were 39 national or international

financial crises between 1945 and 1973.

Their frequency increased to 139 between

1973 and 1997, culminating in the Asian

financial crisis. These crises occurred

predominantly, but not exclusively, in

emerging economies.

Professor Bob Buckle is Pro Vice-Chancellor and Dean, Faculty of

Commerce and Administration, Victoria University of Wellington.
The recent global financial crisis is unusual in a number of important respects. It occurred after a period in which emerging-market-originated financial crises and risk levels seem to have declined substantially (Taylor, 2009, pp.38-9). Also, this crisis occurred after a period of sustained high growth and lower income volatility and sustained low inflation (the 'great moderation'), at least for many developed economies. Moreover, the crisis was triggered not in an emerging economy but in the world's largest and most advanced economy, the United States.

The origins of the global nature of this crisis were not simply US policies. Global economic and financial relationships that evolved over the preceding decades were an important precondition. What is more, the origins have an important AsiaPacific dimension. The crisis arose from a potent constellation of events which included the growth strategies of emerging economies in the Asia-Pacific region. These strategies led to global financial imbalances. These imbalances, when combined with the monetary, fiscal and regulatory policies in the United States, exposed the risks of disintermediation, corporate governance practices and financial innovations, and contributed to a housing bubble. Given the magnitude of the US economy and the seriousness of the financial shock in the US, the crisis reverberated back across the region, and globally, with potentially important implications for the future Asia-Pacific growth process.

\section{Export-biased growth and convergence in Asia-Pacific}

There are several parts to the process that precipitated the recent global financial crisis of 2008 and 2009. One important part was the process of rapid economic growth centred on the Asian region, and in particular the importance of exportbiased growth for China and other emerging economies in the region.

Deng Xiaoping's reforms in China since 1978 and the liberalisation of India's economy after the crisis of 1971 heralded a remarkable period of growth in the Asia-Pacific 
region and what could be described as the 'Third Industrial Revolution'. Together with the more recent emergence of other AsiaPacific economies, such as Vietnam and Peru, and at earlier stages in the region of Korea, Singapore and Chile, for example, these economies have transformed global production chains and global financial linkages and have generated a wealth gain to the world. This wealth gain has been manifest in reductions in the real price of consumption goods. It has also triggered significant terms of trade gains for economies, such as Australia, New Zealand and Canada, supplying raw materials to these rapidly emerging economies. For the AsiaPacific region as a whole, this remarkable transformation resulted in the world's centre of gravity of economic activity gradually shifting towards the region and income convergence in the region (see Buckle and Cruickshank, 2008).

The process of rapid economic growth in the more successful emerging economies was also characterised by a dependence on export-biased growth. There are a number of reasons for this. On the one hand, financial market underdevelopment in emerging economies makes it more difficult for domestic savings generated by higher income growth to be recycled into the local economy. Furthermore, uncertainty with respect to the provision of public goods or social security in public health systems and education systems can lead to precautionary saving and a higher rate of saving overall and hence a lack of domestic recycling of the income growth, particularly if financial markets are underdeveloped.

Export-biased growth became a feature of China's growth process from the early 1990s after it became apparent that domestic demand was not growing fast enough to absorb the rapid investment-led growth in the production of manufactured goods. While retaining investmentdriven growth, there was a switch towards exports and substitution of domestic production for imports to absorb the rapid expansion in manufacturing capacity, particularly in the coastal and urban regions. China in fact became an integrator of global and regional production networks, being a net importer from Japan, Korea, the ASEAN countries, Australia and India and massive net exporter to the US and the European Union (Wong, 2007).

The disruption to growth and economic development caused by the Asian financial crisis in 1997/98 also prompted a stronger emphasis on export-biased growth in the region. Following economic liberalisation, rapid economic growth in these Asian economies resulted in high growth in imports and increased dependence on foreign capital to finance their investment. For many Asian banks, borrowing was in foreign currency while lending was in their national currency. This meant they were exposed to the risk of sharp changes in the exchange rate. When the crisis did occur, banks and corporations suffered severe financial losses. For example, the Indonesian rupiah lost $80 \%$ of its value almost overnight. Bank and corporate foreign currency exposures led to severe losses. Indonesia's GDP fell by $4 \%$ in the first year following the crisis, and it was some three years later before its GDP recovered to the pre-crisis level. South Korea recovered more quickly, as did Malaysia, but Thailand suffered a long period of stagnation after the crisis.

The public sectors in the crisisaffected economies incurred significant fiscal costs to bail out their bankrupt financial systems. Caprio and Klingebiel (2003) estimate that for Indonesia the fiscal cost of the Asian crisis was about $55 \%$ of its GDP. For Thailand the estimate was over $30 \%$, for South Korea about 30\% and for Malaysia about 17\%.

Although one of the consequences of the Asian crisis was that financial systems improved, it also meant that many governments in the region became reluctant to allow their economies to run up current account deficits. There has been a fear of exchange rate floating and a preference to maintain an undervalued exchange rate to support a strong current account position. The Chinese government certainly observed what happened to its neighbours in 1997/98 and concluded that it would not allow anything similar to happen in China.

The Asian financial crisis set the scene for the emphasis in subsequent years on export-biased growth in China and other emerging economies in the region. China's export development model was underpinned by pegging its currency to the United States dollar at an undervalued rate in order to generate trade surpluses and accumulate foreign reserves. In order to give effect to this process, the monetary authority in China has had to sterilise the potential effects on the domestic money supply by issuing government bonds and by increasing the reserve requirements of its financial institutions.

Another lesson of the Asian financial crisis was to ensure robust financial institutions and systems. While this has helped the emerging Asian economies to weather the current crisis, ironically the development of production and financial linkages that have aided growth and convergence in the upswing years, and the dependence on export demand, have also played a significant part in exposing these economies to the contagion effects of the current crisis. What was an advantage in the period leading up to the recent crisis has been exposed as a weakness in this crisis.

\section{Global imbalances (or 'Bretton Woods II')}

The emphasis on export-biased growth, growing current account surpluses and increasing foreign reserves in the 
Asian region, particularly in China, was an important ingredient in the emergence of global imbalances, a savings glut and excess liquidity during the lead-up to the current financial crisis. High domestic saving and large current account surpluses had been particularly evident in China. While Chinese households tended to save at a very high rate, a rise in Chinese corporate savings, including saving by stateowned enterprises, has been at the core of the rapid rise in China's savings (see Wolf, 2009). The government itself has also been a large saver. For similar reasons, the surge in oil prices and oil revenues for oil exporting countries added to the glut of savings in these economies.

The consequential current account surpluses of China, other Asian economies and oil exporting economies were recycled to enable persistent current account deficit economies such as the United States, Spain, the United Kingdom, and the smaller developed Asia-Pacific countries of Australia, Canada and New Zealand to consume and invest far more than their domestic income would otherwise enable. As Hunt (2008) has pointed out, prior to the current crisis there had been a rapid growth in savings in emerging Asia compared to

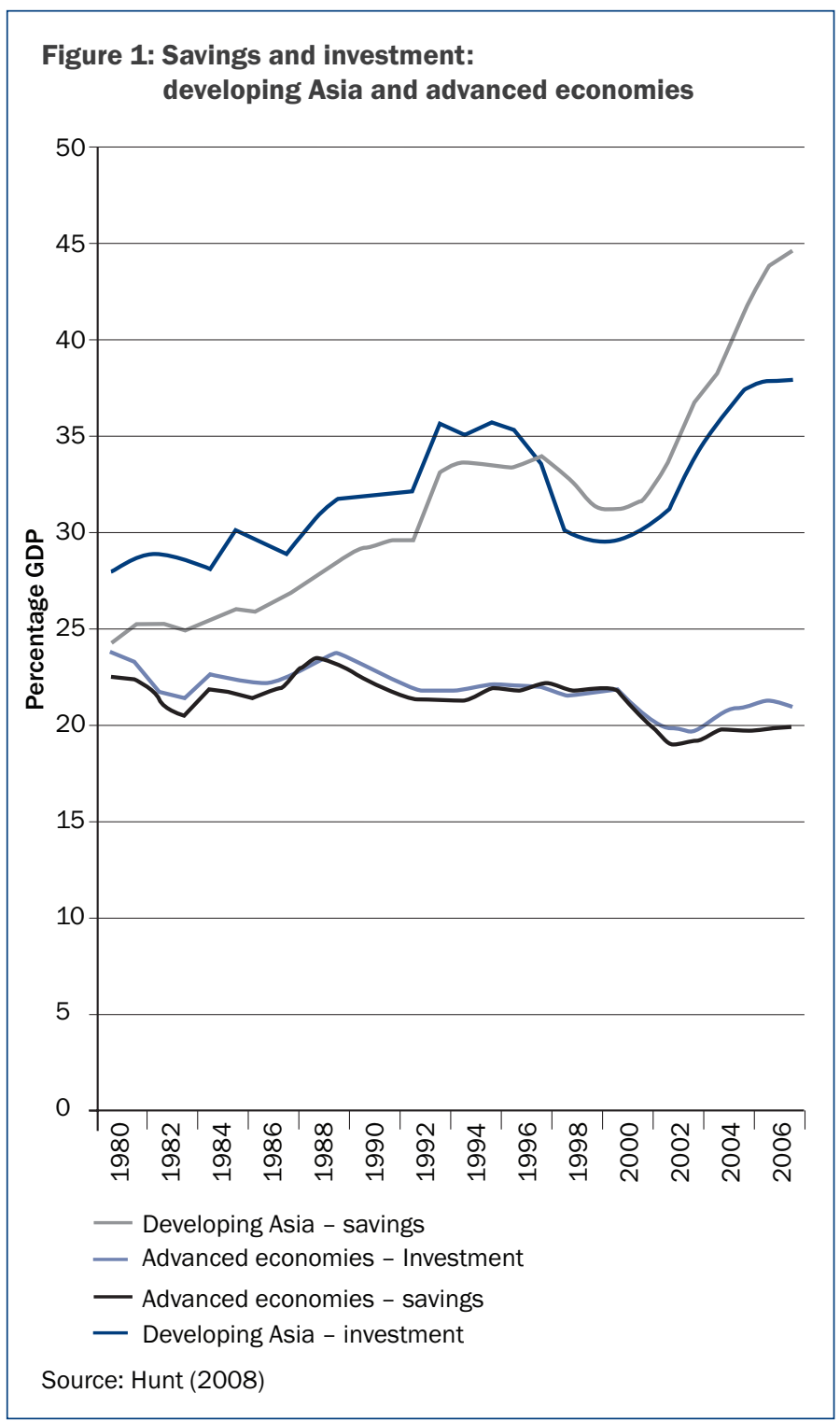

the recovery of investment in this region. In contrast, there had been a secular decline in the investment rates and an even larger fall in savings rates in advanced economies (see Figure 1), a process made possible by the recycling of savings in the former group to finance the dissaving of the latter group.

The IMF (2005) attributes the decline in advanced economy saving rates to increased access to credit facilitated by various financial market innovations, a decline in public saving in some advanced economies such as the United States, and an increase in elderly dependency rates in economies such as Japan. The IMF considers that declining investment rates, particularly in Europe and Japan, are due to demographic trends and reduced investment requirements for industrial economies as a whole. But the key point is that despite stronger investment growth in the emerging economies, saving rates increased even further and despite a secular decline in investment rates in advanced economies, saving rates there declined even further. These differences were manifest in balance of payments current account balances (see Figure 2). The distribution of these balances

\section{Figure 2: Global balance of payments current account balances, 2006}

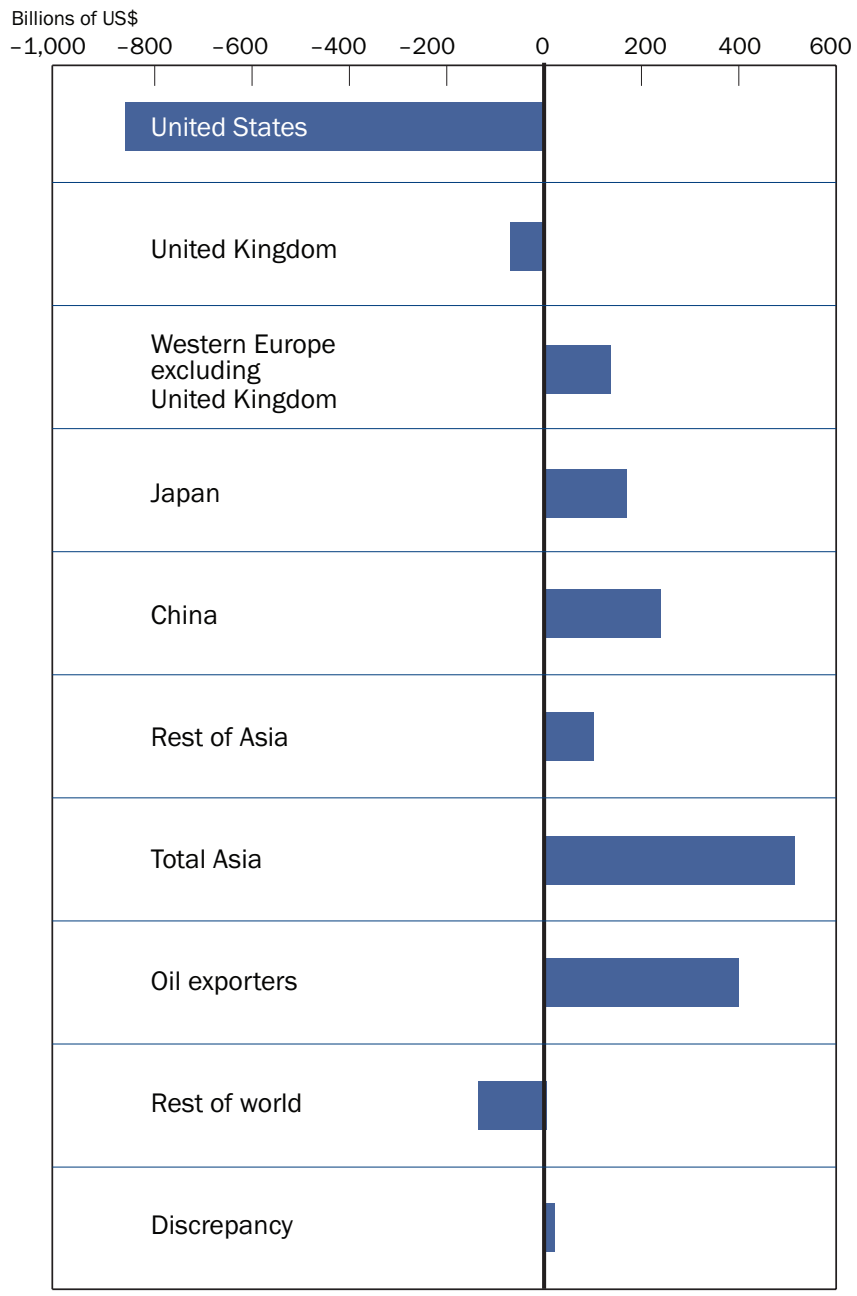

Source: Wolf (2009) 
is reflective of the important financial relationships that emerged, particularly between the world's largest (and highest income) economy, the United States, and many emerging economies, and notably China.

The co-dependence between the respective saving rates, current account balances and corresponding financial capital flows has been termed by Dooley, Folkerts-Landau and Garber (2004a, 2004b) 'Bretton Woods II', in acknowledgement of the similarity to the type of financial arrangements that evolved under Bretton Woods institutions during the postwar years. Under Bretton Woods the reserve currency was also the US dollar. In that era, savings in Japan and Europe supported the US dollar and funded the US current account deficit that was being used to finance US consumption and investment growth, and eventually the war in Vietnam. The system ended in 1971 when US-dollar convertibility into gold was suspended, the US dollar was floated and other countries broke from pegging their currencies to it. ${ }^{2}$

Gurrent account imbalances and the corresponding flows of financial capital can be an important means by which resources in net saving economies are lent to countries that are dissaving. Provided relative prices are able to adjust appropriately, this process can lead to a more efficient global allocation of savings and investment. Sometimes the unwinding of these 'imbalances' is painless, especially when the investment consequent on these transfers generates revenue to warrant the earlier borrowing or dissaving. At other times they can be a painful process, particularly when speculative attacks result in exchange rate adjustments that significantly increase the cost of debt to the borrower countries, as occurred during the Tequila crisis of the mid1990s and the Asian financial crisis of 1997/98.

The global financial imbalances of the new millennium were, however, rather different from past experiences. The direction, at least in net terms, of the capital flows was predominantly from emerging markets to developed economies. Moreover, these flows were dominated by the relationship between China and the US, where China in effect became the banker for the United States. In other words, in Bretton Woods II, the US was the principal destination for this glut of savings in the emerging economies, and the level of savings in China in particular was the largest source of savings. According to Wolf (2008), the US was absorbing about $70 \%$ of the surplus savings in the rest of the world.

Governments in emerging economies were directly responsible for much of the recycling in the form of capital outflows from those economies. This has occurred either because domestic residents were not able to hold foreign assets, as in China, or because most of the export revenue accrued to governments, as in many of the oil exporting economies. Hence there emerged large sovereign wealth funds.

The implication for exchange rates was significant. One of the reasons for such large current account surpluses for emerging economies was the management of exchange rates in order to maintain export competitiveness. The surpluses were used to purchase United States assets, thereby assisting to maintain demand for and the value of the US dollar, preventing it falling against their own currencies. This process has been described as 'vendor financing', in recognition of the fact that countries with large volumes of exports to sell have been financing their biggest market.

A key feature of this process was that, in contrast to borrowing by emerging economies, because it is the issuer of an international reserve currency the US has been able to incur debt denominated in its own currency. This significantly changes the distribution of risk compared to when emerging economies were borrowers leading up to the Asian and Tequila crises, for example. The distribution of risk is relevant when we consider the potential implications for emerging Asia-Pacific economic relationships and growth in the postcrisis period.

All else being equal, an excess of investment over savings, as has occurred in the US and other advanced economies, should lead to an increase in long-term interest rates in those economies. However, the Bretton Woods II process of intermediation had the effect of providing easy credit and depressing United States and global long-term interest rates (see Figure 3).

The process of global imbalances and global intermediation had another important effect. By recycling savings to purchase US financial assets and supporting the US dollar, the resulting elevated real exchange rate for US tradable goods and services disadvantaged producers in that sector, causing it to shrink (as manifest in the current account deficit). The reason this didn't result in a much earlier recession in the US is that, in contrast to the household sector in China, the household sector in the US was dissaving and maintaining high rates of demand for non-traded goods, particularly high rates of residential investment. An expansionary US fiscal policy was another important factor sustaining US non-tradable demand.

\section{United States policy: triggering and prolonging the crisis Politicising the housing market}

Prior to the outbreak of the current crisis, property price booms had been spreading across several economies. In 2006 nominal house price inflation exceeded $10 \%$ in eight out of 18 OECD economies. This boom was particularly evident in, but not restricted to, Anglosphere countries (the US, UK, 
Figure 3: Global long-term interest rates

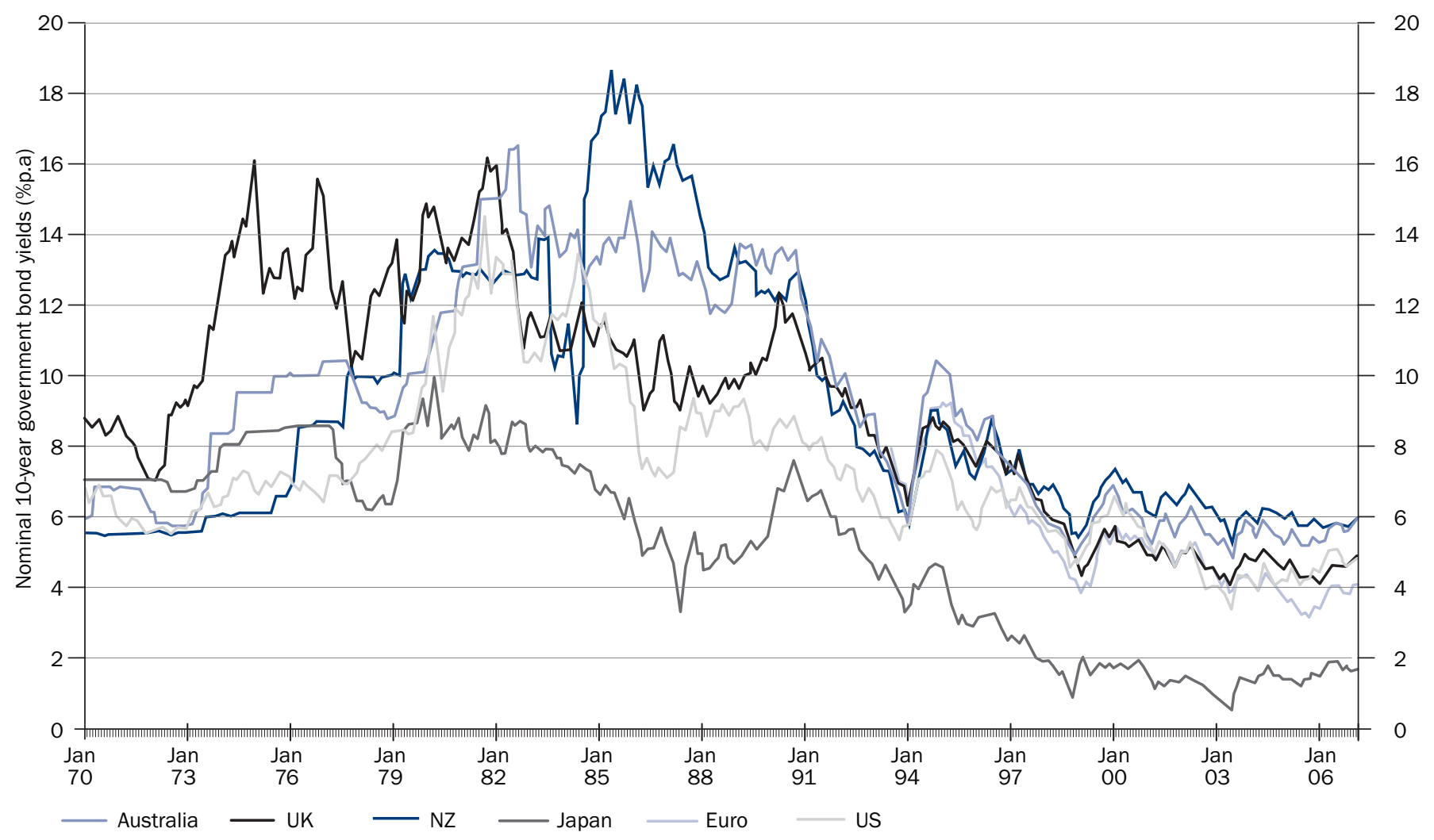

New Zealand, Ireland, Canada, Australia), described by Ferguson (2008) as the first property-owning democracies. For the United States, the basis of this property-owning democracy was developed particularly during the latter part of the Great Depression. The New Deal introduced many of the institutional features of current US housing policy which have underpinned the US housing market. Indeed, Ferguson suggests that the most successful and enduring component of the New Deal was how it transformed the US housing market.

During the Depression, US mortgages were typically short-term, and were not amortised. The establishment of the Federal Housing Administration provided federally-backed insurance for mortgage lenders, and encouraged large, longterm, fully amortised low-interest loans (Ferguson, 2008). The foundation for a national secondary market was established with the introduction of the Federal National Mortgage Association ('Fannie Mae'), authorised to issue bonds and use the proceeds to buy mortgages from local Savings and Loans associations (S\&L). S\&Ls became the foundation for growing property ownership in the post-Depression years. ${ }^{3}$

From the 1930s onwards the US government was effectively underwriting the mortgage market (Ferguson, 2008). Before the 1930 s about $40 \%$ of American homeowners were owner-occupiers. Today that figure is close to $70 \%$ as it is in other parts of the Anglosphere).

This structure came under threat in the late 1970s and 1980s when, in the wake of Paul Volcker's higher interest rate anti-inflation strategy, less regulated financial institutions were able to compete more effectively for deposits. To restore the position of Savings and Loans associations, the
Carter and Reagan administrations provided tax breaks and deregulation (see Ferguson, 2008, p.254). The crisis resulting from the mismatching of assets and liabilities, and fraudulent practices, was a clear lesson in the consequences of well-intentioned but poorly designed regulation. It did not have the global implications of the current crisis, but it provided the opportunity for investment banks and the less regulated financial sector to establish a stronger presence in the mortgage market and to develop financial instruments such as mortgage-backed securities. ${ }^{4}$ Moreover, the majority of mortgages still qualified for an implicit guarantee from the government-sponsored enterprises (GSEs) 'Fannie Mae', 'Freddie Mac', and 'Ginnie Mae'. ${ }^{5}$

Politicisation of the housing market continued under the Bush administration, as highlighted by President Bush in December 2003 when he remarked: 'it is in our national interest that more people own their home' (cited in Ferguson, 2008, p.267). The combination of declining real interest rates, political support and financial innovations appeared to have markedly boosted home ownership. In the ten years from 1995 to 2005, home ownership increased from $64 \%$ to around $70 \%$. Ferguson (2008) suggests that half of that can be attributed to the sub-prime lending boom.

\section{The sub-prime crisis}

The history of financial crises suggests that financial deregulation tends to be followed by financial innovations. These innovations can lead inadvertently to higher risk which raises the probability of financial failure. In recent years, many countries have abolished regulations limiting the range of activities in which their banks can engage. One 
explanation for these regulatory reforms is that this enables greater diversification of assets and liabilities needed to withstand shocks (Adalet, 2007). In the US, the Glass-Steagall Act (1933) restricting commercial bank involvement in investment banking was abolished in 1999. This removed restrictions on mixing commercial and investment banking, and it allowed commercial banks, and insurance companies like AIG, to encroach on the traditional investment banking services.

Eichengreen (2008) observes that while this was basically sensible policy, based on a model that had proved viable in Germany and other parts of Europe, in the US financial environment it had serious unintended consequences. Investment banks were forced to develop new lines of business to sustain their profitability. It created an environment that prompted the originate-and-distribute model of securitisation, the extensive use of leverage and the growth of the sub-prime mortgage market. ${ }^{6}$

The sub-prime model relied on low interest rates, rising real estate prices and mortgagees maintaining their ability to service the mortgages. Taylor (2009) suggests there is a dynamic interaction that tends to accentuate risk-taking. When house-price inflation is high there is a tendency for housing foreclosure and delinquency rates on adjustable-rate sub-prime mortgages to fall. This probably reflects the benefits of holding onto a house and working longer hours to meet the mortgage payments when house prices are rising rapidly. The declining rates of foreclosure and delinquency that occurred in the US during the early part of the millennium may have confused many, including rating agencies, as to the true extent of risk. This problem would have been accentuated by the complex securitisation techniques that evolved during this period and led to what Taylor has described as the 'Queen of Spades problem' - where people don't know which securities had the bad mortgages in them.

Repackaged as collateralised debt obligations (CDOs) and with the assistance of favourable credit ratings, these sub-prime securities were transformed from risky loans into highly-rated investment-grade securities. The risk was spread across the globe to institutions seeking what were thought to be secure returns for pension funds, insurance funds, etc. However, the process accentuated the information asymmetry risks. Ferguson nicely captures the information risks:

Those who knew best the flakiness of sub-prime loans the people who dealt directly with the borrowers and knew their economic circumstances - bore the least risk. They could make a 100\% loan-to-value 'NINJA' loan (to someone with no income, no job, or assets) and sell it on the same day to one of the big banks in the CDO business. In no time at all the risk was floating up a fjord (Ferguson, 2008, p.269)
'Light touch' regulation in the US (and in the UK and parts of Europe), fragmented regulatory systems and failures of supervision are therefore considered by some to have played an important part in enabling the development of markets for CDOs and the global spread of these securities (see the discussion in Henderson, 2009). This process of globalising the risk exposed not just the US financial system but many parts of the global financial system to greater risk of contagion. When the Federal Reserve did start to raise interest rates from late 2004 through to 2006, huge numbers of sub-prime mortgage holders were not able to service the renewed higher mortgage interest rates, causing foreclosures which burst the real estate bubble. From 2006, US house prices started to fall for the first time since the early 1990s, and housing starts dropped like a stone. By 2007 the collapse of the US subprime mortgage market was reverberating across the United States and global financial markets.

\section{US monetary policy: too late and off target?}

The role of the US Federal Reserve and monetary policy is still hotly debated. During the early part of the new millennium, the Federal Reserve decisions were primarily concerned with the sharp slump in GDP growth, following the collapse of the dot.com bubble, a fear of the deflation that had plagued Japan in the 1990s and the impact of 9/11. To boost demand, the Federal Reserve quickly lowered the federal funds rate from around $6.5 \%$ to below $2 \%$ in late 2001. The rate was then gradually reduced to $1 \%$ and held there until early 2004.

Taylor (2009) is of the view that the Federal Reserve allowed this loose monetary policy to go on for too long. His argument is based on a comparison of Federal Reserve funds rate decisions from 2002 to 2006 with federal funds rate decisions that would have been made had the Federal Reserve followed the same decision-making rule used during the period of 'great moderation'. He argues that Federal Reserve interest rates in the period 2001-2004 represented an unusually large discretionary deviation from the usual decision rule. They fell well below what historical experience suggested the policy response should have been, and accentuated the US housing boom. This sharp easing in monetary policy contributed to the subsequent upswing in the business cycle and inflation, and therefore the eventual decision to lift interest rates sharply again from 2005 to 2006, decisions that were more in line with early monetary policy. While the period of low interest rates helped fuel the subprime mortgage market, the sudden reversal of interest rates contributed to the collapse of that market.

If this argument is correct, then the break in interest rate policy may not have been restricted to the United States Federal 
Reserve alone. Ahrend, Cournède and Price (2008) argue that deviations from the 'Taylor rule' by central banks in several other countries contributed significantly to the housing booms in those countries. They demonstrate that countries with the largest interest rate deviations below what previous policy rules would have predicted experienced the biggest housing investment booms.

On the other hand, some consider it not credible to blame all the US excesses of recent years on US monetary policy (see, for example, Ferguson, 2008, p.267). Dunaway (2009) considers that because the yield curve in the US was relatively flat in the early part of the decade in response to the global 'savings glut', Federal Reserve increases in short-term rates may not have fully passed through into long-term rates.

It is difficult to identify the relevant weights we should attach to central bank interest rate decisions and the glut of savings from emerging economies in contributing to the global decline in real interest rates and the housing boom. What is clear is that this was a global phenomenon. The global connections could be explained by national monetary policies reacting to potential exchange rate appreciations that could have been prompted either by the glut of savings in emerging economies lowering global long-term real interest rates, or in response to the US Federal Reserve decisions to lower interest rates. Under either argument, central banks around the OECD economies would be observed to be simultaneously lowering short-term interest rates. These two arguments seem to be observationally equivalent.

\section{Did US policy prolong the crisis?}

Many have suggested the crisis can be dated from June 2007, when two hedge funds owned by Bear Stearns were revealed by Merrill Lynch to be insolvent. Bear Stearns bailed out one fund but let the other collapse. Rating agencies subsequently began downgrading residential mortgage-based CDOs and by the end of 2007, American Home Mortgage had filed for bankruptcy, mortgage investment funds were being suspended, Northern Rock was nationalised by the government in the UK, numerous hedge funds were wound up, and asset writedowns by banks eliminated hundreds of billions of US dollars from their balance sheets. What is more, the governmentsponsored Fannie Mae (which under encouragement of government policy had significantly increased its share of US mortgages) was placed in serious risk of collapse.

US policy makers have also been criticised for prolonging the crisis. The US Treasury and Federal Reserve initially interpreted the crisis as if it was a liquidity problem. The Term Auction Facility (TAF) and the 2008 Economic
Stimulus Package, and even the initial cuts in the Federal funds rate in the early part of the millennium (which contributed to a lower exchange rate and higher oil prices in US dollars) were focused on improving liquidity. However, Taylor and Williams (2009) argue that the principal underlying problem was one of 'counterparty risk'.

The decline in house prices, reduced job security for homeowners and higher risk of bankruptcy are likely to have increased the risk of deterioration in bank balance sheets, causing greater concern about counterparty risk. Banks were criticised for not lending to traders or being reluctant to lend to each other. This has commonly been interpreted as a liquidity problem, whereas in fact the underlying problem may have been that banks were more concerned with counterparty risk.

The Taylor and Williams critique, and criticism by others such as Anna Schwartz (2008), implies that there was in the US, and possibly elsewhere, an initial diagnosis error by policy institutions, and implies that policy errors by policy makers not only sparked the crisis but may also have prolonged it. In any event, perceived risk levels seem to have declined following the implementation of the Troubled Assets Relief Programme and the introduction of guarantees by the Federal Deposit Insurance Corporation, Federal Reserve support for the Commercial Bills Market and similar actions in other countries.

\section{Prognosis and implications for Asia-Pacific growth}

The IMF has described the current global situation as the outcome of 'the largest financial shock since the Great Depression' (IMF, 2009a). The collapse of the US housing and sub-prime lending markets, and the spread of toxicated assets across the financial centres of Europe, had such a powerful domino effect that what started as a financial shock turned into a global production slump. In October 2009 the IMF forecast an annual decline in global GDP in 2009 of $1.1 \%$ (IMF, 2009b). This compares to growth of $3 \%$ in 2008 and $5.2 \%$ in 2007 , and represents a negative turnaround of over $6 \%$ growth in two years! (see Figure 4 ). If this proves correct, it will be the first annual fall in world GDP in the postwar era.

These forecasts reflect a feature of this global recession that Bollard and Ng (2009) consider distinguishes it from previous global recessions of the postwar era. The financial crisis spread quickly from the US to Europe, reflecting the direct vulnerability of Europe's financial sector to the USoriginated credit exposures, as well as the adverse relaxation of credit standards within Europe itself. The eventual spread to emerging economies, including China and many other parts of the Asia-Pacific region, has been primarily through trade and commodity price channels. The financial shock 
had an adverse impact on confidence and wealth in advanced economies, causing a slump in consumer and investment demand, thereby transmitting the shock to the traded-goods sectors and to commodity prices via the traditional channels. The IMF expects the volume of world trade to fall by $11.9 \%$ in 2009 and commodity prices to fall by $30.6 \%$ for oil and 20.3\% for non-oil commodities.

This unusual characteristic is reflected in the IMF forecasts, which are for advanced economy GDP to fall by 3.4\% this year, a growth reversal of $6.1 \%$ in two years. Emerging and developing economy GDP growth is expected to grow by only $1.7 \%$, a growth reversal as severe as for developed economies. China and India are expected to be more resilient and grow by $8.5 \%$ and $5.4 \%$ respectively in 2009 , but this is still below growth in the previous two years.

How will this crisis and the ensuing global recession influence the Asia-Pacific growth process in the future? The global financial crisis has exposed the weaknesses of the precrisis model of export-biased growth dependent on US and EU domestic demand growth. What had been an advantage for emerging economies under Bretton Woods II prior to the

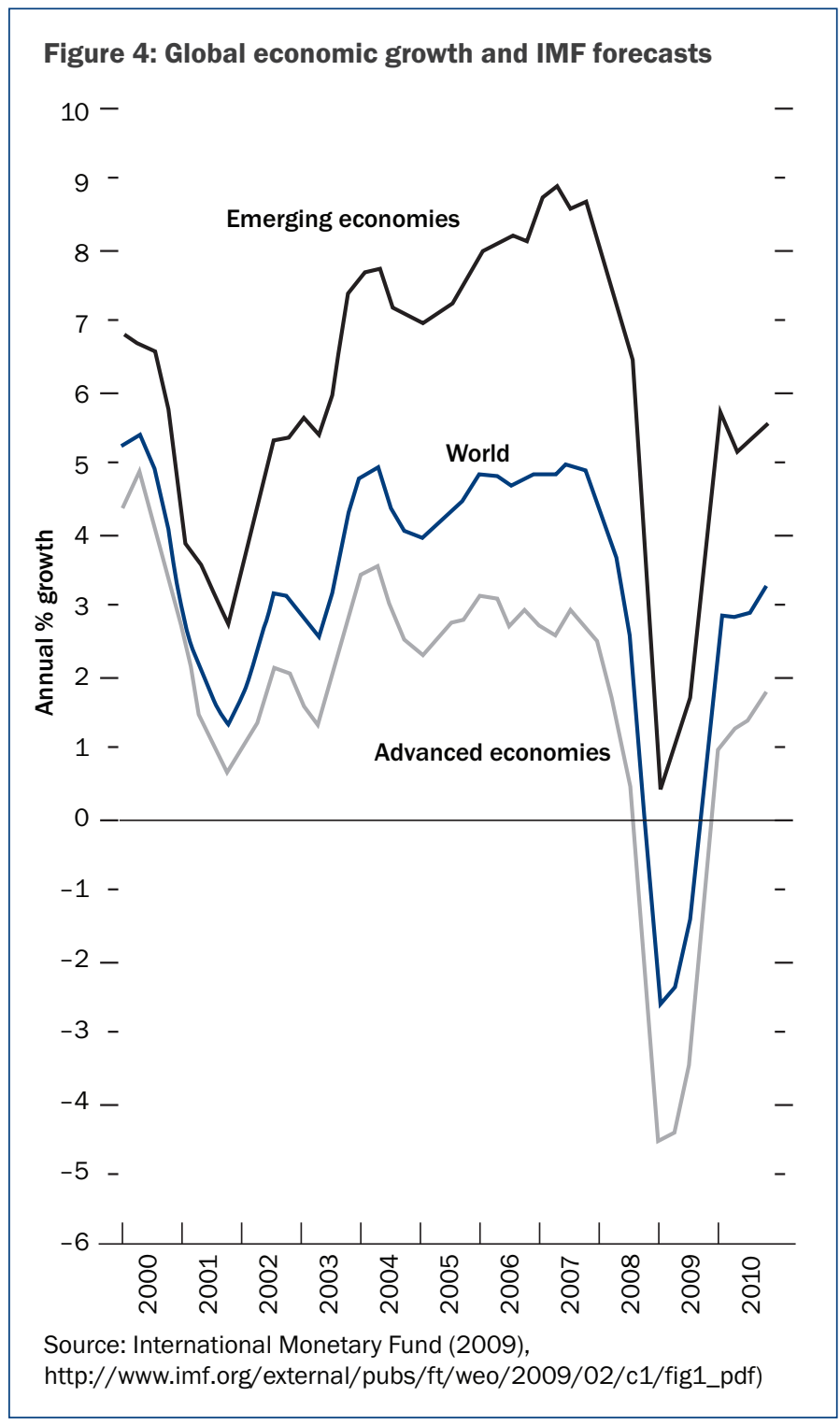

crisis has proved to be a weakness during the crisis.

While the lessons of the Asian financial crisis were absorbed and have been applied to improve the resilience of financial markets in the Asian region, the effects of the current crisis are particularly apparent in the collapse of exports in the region. The inevitable slump in China's exports has been accompanied by a decline in China's import growth and hence its demand for output from other Asian economies. Cyclically sensitive high-tech manufacturing exports were hit particularly hard and Asian manufacturing exports were more severely affected than during the dot.com crash and the late 1990s Asian financial crisis (IMF, 2009a). This was particularly the case in Thailand, Singapore, Korea, Taiwan, Malaysia and Japan (Figure 5). Asia's tightly integrated supply chain, a feature that promoted high growth during the preceding decade, propagated the effect of the US and European slump across the region.

Furthermore, the risks to emerging economies of the Bretton Woods II model of 'vendor financing' have also been exposed. Foreign central banks, like China's, and sovereign wealth funds that have invested in US Treasury and other

Figure 5: Asian high-tech manufacturing exports

10

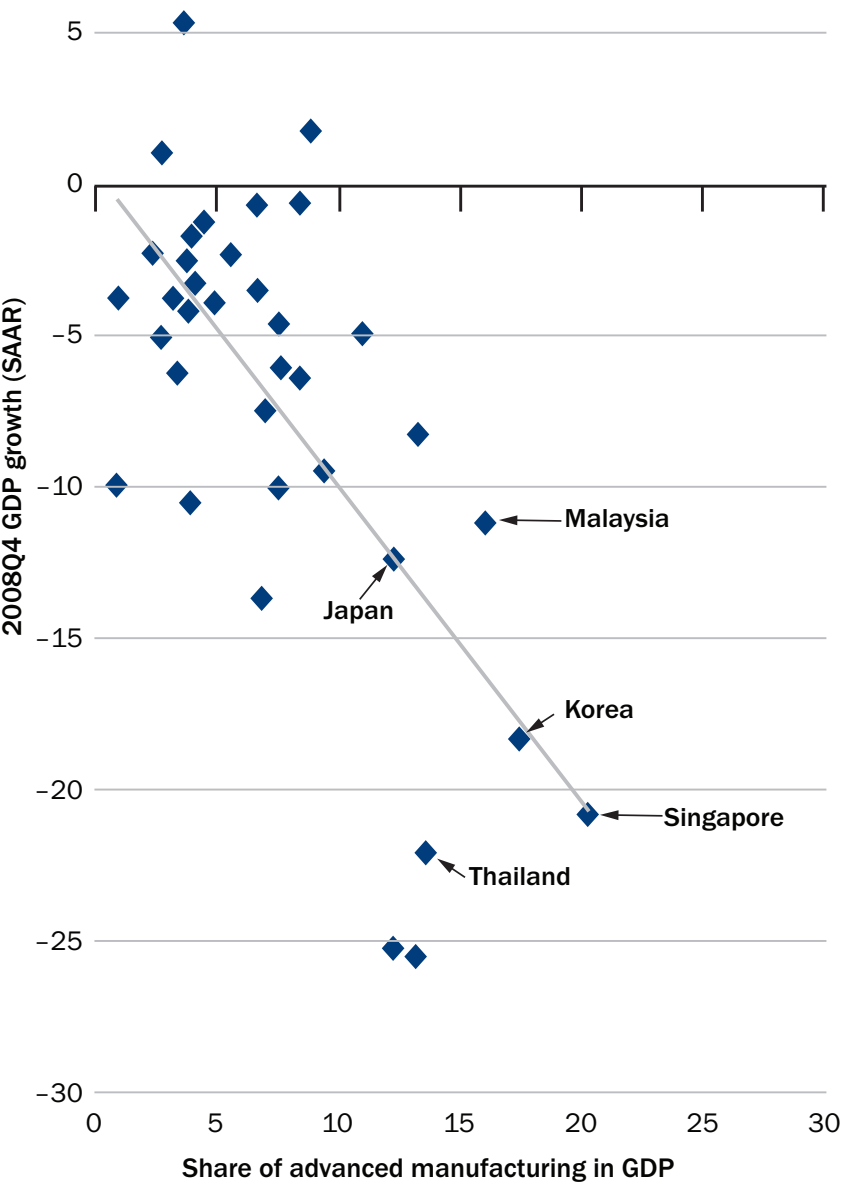

Source: International Monetary Fund (2009a) 
agency securities and which have financed the large US current account deficits of recent years, have suffered immense capital losses. Moreover, because these investments are typically denominated in US dollars, the reserve currency, they are highly exposed to exchange rate risk. Foreign central banks and sovereign wealth funds holding US dollardenominated assets remain vulnerable to a fall in the value of the US dollar should the Bretton Woods II model not be sustainable. ${ }^{8}$

An alternative future growth scenario is one in which saving rates in developed economies increase or growth continues to stagnate, and there is a shift away from the heavy reliance on export-biased growth by China and emerging economies and a greater reliance on domestic demand to sustain production.

Declines in house prices and financial wealth have affected consumption spending in the US as households attempt to rebuild wealth. US household saving is rising and is expected to continue to rise above its current level (Dunaway, 2009). Furthermore, the effectiveness of the Federal government fiscal expansion plans has been hindered by concerns at the prospect of an emerging fiscal crisis in the US and by attempts by many state governments to restore their fiscal balances. The US Federal fiscal deficit is expected to be $5.5 \%$ of GDP by 2019, and national debt accumulate to the levels immediately after World War Two when the US was paying off war debts (Auerbach and Gale, 2009). At some point US government saving will also have to rise. Europe and Japan also seem unlikely to provide an alternative source of demand recovery. There seems little scope for fiscal and consumption-based growth in Japan, which seems likely to remain dependent on export demand, particularly from China.

Attention therefore inevitably turns to Asia, and in particular whether China will be able to rely more on domestic demand as the engine of growth. Many commentators have noted the sectoral and geographical imbalances and the income inequality and rural discontent that China's growth process has to date created. The Chinese leadership had been aware of the need for change even before the global financial crisis. At the fifth Party Plenum in October 2005 the 11 th Five-Year Plan was adopted, calling for a redirection of China's growth strategy, one that is more broad-based and more balanced and sustainable (Wong, 2007). The global situation since the financial crisis has provided further impetus for change in China. China has started to move more strongly in this direction by instructing state-owned enterprises to invest reserves in domestic infrastructure and to maintain employment and boost domestic spending. It is also converting its huge stock of foreign reserves into claims on resources around the world. But China still faces a difficult transition, that will require financial reforms (to improve the intermediation of savings) and the removal of price distortions (including the low cost of capital and undervalued exchange rate) that have underpinned the investment and export-biased growth process of the previous stage of its development.

It seems unlikely therefore that the Asia-Pacific growth model based on export-biased growth from emerging economies and vendor financing of imports by developed economies (the US in particular) will be sustained in the post-crisis era. If advanced economies start to save more as households start to restore housing equity and governments start to tackle the fiscal deficits that have rapidly emerged from the crisis, external deficits in developed economies will start to decline in the post-crisis era. Higher saving rates by advanced economies will impact on the export and foreign investment environment for emerging economies.

If saving rates do rise in advanced economies, sustained growth convergence that has characterised the Asia-Pacific region during the past two decades will require lower saving rates in emerging economies and a greater dependence on domestic demand to restore their relatively high growth rates. But a new model based on stronger domestic demand growth in emerging economies will require sectoral rebalancing, and structural and real exchange rate changes that enable these economies to attract a greater share of domestic and advanced economy savings. The transition to this new model will take time and may result in slower Asia-Pacific and global growth in the immediate future, but it may also provide a more robust basis for sustained growth and reduced risk of financial crises.

\section{Conclusion}

The recent financial crisis resulted from the conjuncture of events that included growth strategies and exchange rate policies in emerging economies, investment decisions of central banks in these emerging economies, including oil exporting economies, the financial innovations that were spurred by US regulatory changes, and corporate governance practices. Previous postwar financial crises in the US, such as the Savings and Loans crisis, did not have the same global impact that the recent crisis had. The conjuncture of US and European financial practices and emerging economy growth strategies propelled the collapse of the US sub-prime mortgage market into the worst global financial shock and recession of the postwar era.

The crisis exposed the risks of globalimbalances (or Bretton Woods II) of the last two decades, and the vulnerability this process presents for emerging economies striving to 'catch up'. The risks of the model of export-biased growth were exposed. If the Asia-Pacific region is to restore its position as the engine of global growth, if emerging economies are to retain the impressive rates of growth and convergence of 
the last two decades, a new growth model will be needed, one more dependent on domestic demand growth and recycling of saving towards, rather than away from, those economies.

Theimplications for developed economies on theperiphery, such as New Zealand and Australia, will be important. The success of the growth transition in China, and other emerging economies in the region such as Vietnam, will have an even more important impact on commodity prices and on the opportunities to exploit these growing markets, particularly if the US economy fails to recover to the growth rates of the pre-crisis era. Similarly, the diversification of Asian saving away from the US market could have a significant impact on exchange rates in these countries, particularly if China continues to manage its exchange rate. The global financial crisis may not necessarily be epoch-defining, but it seems certain to provoke a significant change in Asia-Pacific growth dynamics.

\footnotetext{
1 This article is a revised version of presentations to the 'World Class Practices in Management Education' conference at Fudan University, Shanghai, China, 31 May-2 June 2009; Victoria University of Wellington MBA 25 years celebrations, http://www.victoria. ac.nz/vms/study/postgraduate/mba/25thCelebrations.aspx; and the Lee Foundation Lecture, University of Economics, Ho Chi Minh City, Vietnam, 29 August 2009. I am grateful to Muge Adalet, Alan Bollard, Amy Cruickshank, Gary Hawke and John McDermott for their helpful conversations and suggestions during preparation for these various presentations, and to Jonathan Boston for editing suggestions.
}

2 There have been other periods when global savings flowed from one region to another. An example is the pre-World War One gold standard period, when the industrial economies of Britain, France and Germany financed the development of resource-intensive regions such as Australia, Canada, New Zealand and some of the southern-cone economies of South America.

3 The New Deal also introduced federal deposit insurance, while mortgage interest payments had been tax deductible since the inception of the federal income tax in 1913.

4 In 1980 only $10 \%$ of the US home mortgage market had been securitised, but by 2007 this proportion had risen to $57 \%$ (Ferguson, 2008, p.260).

5 In 1968 the operations of Fannie Mae were split in two: the Government National Mortgage Association (Ginnie Mae), catering to poor borrowers, and a re-chartered Fannie Mae established as a privately-owned government-sponsored enterprise (GSE). Two years later, to provide some competition in the secondary market, the Federal Home Loan Mortgage Corporation (Freddie Mac) was established. The effect was to again broaden the secondary market for mortgages and, in principle, provide lower mortgage rates.

6 Henderson (2009) provides an excellent description of the 'originate-and-distribute' model of housing finance and the information asymmetries that emerge by breaking the process into five critical links: the originator, the packager, the rating agency, the repackager and the credit insurer.

7 Counterparty risk is a situation in which banks become reluctant to lend to each other because of the perception that the risk of default on loans has increased and the market price of taking on such risk has risen. This situation requires a focus on the quality and transparency of bank balance sheets.

8 Concerns about the sustainability of the Bretton Woods II model and emerging economy vulnerabilities prompted calls to boost resources for international financial institutions. The G20 leaders, for example, agreed at a meeting in London in March this year to strengthen financial supervision and regulation and make an additional US $\$ 850$ billion in resources through international financial institutions such as the IMF (including a boost to SDR allocation), World Bank and other multilateral development banks, and to speed up reform of these institutions to ensure national representation is more in line with the changing global economic balance.

\section{References}

Adalet, M. (2007) 'The effects of financial structure on crises: universal banking in interwar Europe', working paper

Ahrend, R., B. Cournède and R. Price (2008) Monetary Policy, Market Excesses and Financial Turnover, Economics Department working paper 597, OECD

Auerbach, A.J. and W.G. Gale (2009) 'The economic crisis and the fiscal crisis: 2009 and beyond. An update', http:// www.brookings.edu/ /media/Files/rec/ papers/2009/06_fiscal_crisis_gale/06_ fiscal_crisis_gale.pdf

Bollard, A. and T. Ng (2009) 'Coping with global financial and economic stresses', address to the Canterbury Employers' Chamber of Commerce, 30 January, http://www.rbnz. govt.nz/speeches/3507679.html

Buckle, R.A. and A.A. Cruickshank (2008) 'APEC moves behind-the-border: evidence that structural reform will hasten income convergence in the Asia-Pacific region', Agenda, 15 (4), pp.19-34

Caprio, G. and D. Klingebiel (2003) 'Episodes of systemic and borderline financial crises', World Bank, http://www.worldbank.org

Dooley, M.D., D. Folkerts-Landau and P.M. Garber (2004a) 'The revised Bretton Woods system', International Journal of Finance and Economics, 9 (4) October, pp.307-13

Dooley, M.D., D. Folkerts-Landau and P.M. Garber (2004b) The US Current Account Deficit and Economic Development: collateral for a total return swap, working paper 10727, National Bureau of Economic Research

Dunaway, S. (2009) 'Global imbalances and prospects for the world economy', NZIER working paper 2009/5, http://www.nzier. org.nz/Site/News/default.aspx

Eichengreen, B. (2008) 'Anatomy of the financial crisis', September

Eichengreen, B. and M.D. Bordo (2002) Crises Now and Then: what lessons from the last era of financial globalization?, working paper 8716, National Bureau of Economic Research

Ferguson, N. (2008) The Ascent of Money: a financial history of the world, New York: Penguin

G20 (2009) 'Global plan for recovery and reform', official communiqué issued at the close of the G20 London summit, 6 April, http://www.londonsummit.gov. uk/resources/en/news/15766232/ communique-020409

Henderson, D. (2009) 'The financial crisis: what happened and why?', ANU public lecture series, 21 July, http://www.anu. edu.au/doscoveranu/content/podcasts / financial_crisis_what_happened_and_why/

Hunt, C. (2008) 'Financial turmoil and global imbalances: the end of Bretton Woods II?', Reserve Bank of New Zealand Bulletin, 71 (3), September, pp.45-55

IMF (2005) 'Globalization and external imbalances', World Economic Outlook, April

IMF (2009a) 'Global economic policies and prospects', report to G20 meeting of ministers and central bank governors, London, 13-14 March, http://www.imf.org/ external/np/g20/pdf/031909a.pdf

IMF (2009b) 'World economic outlook: sustaining the recovery', October, http://www.imf.org/external/pubs/ft/ weo/2009/02/c1/fig_9.pdf

King, R.G. and R. Levine (1993) 'Financing growth: Schumpeter might be right', Quarterly Journal of Economics, 108, August

Schwartz, A. (2008) Interview in Wall Street Journal, October

Taylor, J.B. (2009) Getting Off Track: how government actions and interventions caused, prolonged, and worsened the financial crisis, Stanford: Hoover International Press

Taylor, J.B. and J.C. Williams (2009) 'A black swan in the money market', American Economic Journal: Macroeconomics, 1 (1), pp.58-83

Wolf, M. (2009) Fixing Global Finance: how to curb financial crises in the 21st century, New Haven: London: Yale University Press Wong, J. (2007) 'China's economic growth in East Asian context', in J. Wong and W. Lui, China's Surging Economy: adjusting for more balanced development, Singapore: World Scientific 